\title{
UNIVERSITY DEVELOPMENT IN BRITAIN
}

$\mathrm{T}$ $\mathrm{HE}$ report of the University Grants Committee on University Development $195 \%-62 *$ reviews first the work of the Committe during 1957-62, recapitulating some matters that have received comment earlier either in the interim report on development 1957-61 or in the surveys which now preface the Committee's annual roturns. The second chapter summarizes the main developments of the quinquennium, and although here again earlier material is freely repeated the picture now presented is more complete. Next the report reviows university expansion over the whole period 1946-73; chapters on the new universities, on the growth and control of capital expenditure, on academic salaries and staffing follow, while the report is completed by two chapters on the universities and national needs and on the role of the Committee and the working of the quinquennial system. The last chapter and the Committee's comments on teaching and research are discussed on p. 523 of this issue of Nature. The present summary deals essentially with the second chapter and with other material in the report which has not been previously noted in Nature.

During the quinquennium, full-time undergraduate students increased by $22 \cdot 6$ per cent to 93,781 , postgraduate students increasing by $50 \cdot 6$ per cent to 15,831 and those studying for a teacher's diploma by 23 per cent to 3,531 . Entrants for first degrees and diplomas increased by $25 \cdot 8$ per cent to 32,160 , and the number of students obtaining a first degree or diploma by 28.7 per cent to 24,674 ; for a higher degree the figures stand at 36 per cent and 9,987 . By faculties the increase in full-time students in 1961-62 compared with 1956-57 was: arts and social studies, 25.5 per cent; science, 44.1 per cent; applied science, 37.9 per cent; dentistry, 11.3 per cent; agriculture and forestry, $7 \cdot 1$ per cent; veterinary science, $11 \cdot 5$ per cent; there was a decrease of $5 \cdot 3$ per cent in medicine. On an average 27.7 per cent of full-time students came from within 30 miles of their university, $60 \cdot 8$ per cent from other parts of the Unitod Kingdom, $6 \cdot 7$ per cent from other parts of the Commonwealth and 4.8 per cent from foreign countries. In 1938-39 the corresponding percentages were $45 \cdot 8,43 \cdot 8,5 \cdot 7$ and $4 \cdot 7$, respectively, and in 1956-57, $33 \cdot 9,55 \cdot 1,6 \cdot 8$ and $4 \cdot 2$. In $1961-62,31,820$ full-time students during term were in colleges or halls of residence, 58,382 in lodgings, and 22,941 lived at home; the corresponding figures for $1956-57$ were $24,652,41,291$ and 23,923 , respectively. The proportion of students in residence varies greatly between institutions--in England and Wales, from 97 per cent at the University of Keele to 10 per cent at the University of Birmingham; in Scotland, from 54 per cent at St. Androws to less than 3 per cent at the Royal College of Science and Technology, Glasgow.

The proportion of assisted students continued to rise. Whereas, in 1934-35, 41.7 per cent of full-time students were assisted in whole or in part from public or private funds, in 1956-57 the percentags was 75.7 and in 1961-62 it was $87 \cdot 1$; for England as a whole it was $87 \cdot 3$ per cent, for Wales 95.3 per cent and for Scotland 83.5 per cent, where it rose from 61.7 per cent during the quinquennium. Further enquiries during the quinquennium into the success or failure of students indicated that 82.8 per cent of first-degree students admitted in October 1957 had succeeded in obtaining their first degree, 3 per cent had been re-admitted and 14.2 per cent had left without success; these figures compare with 83,3 and 14 per cent,

* University Grants Committce. University Development 195\%-62. Pp. $x+230+11$ photographs. (Cmnd. 2267 .) (London: H.M. Stationery Office,
1964 .) 15s. net. (See also p. 523 of this issue of Nature.) respectively, for students admitted in October 1955. In applied science, however, only 72.5 per cent were successful and 20.8 per cent left without success, the 1955 figures being very similar; engineering departments are studying this problem closely. Again only 56.8 per cent of the students in medicine, dentistry and veterinary scionce were successful in the normal period and 30 per cent of students in these clinical subjects were successful in more than the normal period; only 10.9 per cent left without success. Of degrees obtained in 1961-62 in arts and social studies, $80 \cdot 2$ per cent were honours and $19 \cdot 8$ per cent ordinary degreas; in science the corresponding figures are $74 \cdot 6$ per cent and $25 \cdot 4$ per cent; and in applied science 67.6 per cent and 32.4 per cent. In science $9 \cdot 7$ per cent were first-class honours degrees, $16 \cdot 3$ per cent second-class honours (upper division), $22 \cdot 8$ per cent secondclass honours (lower division) and $9 \cdot 0$ second-class honours (undivided); in applied scienco the corresponding percentages were: $9 \cdot 1,17 \cdot 3,21 \cdot 7$ and $4 \cdot 0$. In $1961-62,3,279$ first-degree graduates in science undertook further education or research, 352 entered the public service at home, 708 education, and 1,516 industry and commerce. For applied science the corresponding figures are $723,268,80$ and 2,177 .

During the quinquennium, full-time academic staff employed in the universities increased by 25 per cent from 10,485 in the last year of the previous quinquennium to 13,104 in 1961-62, compared with a student increase of 25.9 per cent. The number of professors increased by 17.1 per cent to 1,708 ; readers and others of equivalent status increased by $27 \cdot 3$ per cent to 964 ; senior lecturers, by 41.6 per cent to 1,602 ; lecturers, by 22.8 per cent to 6,021 ; assistant lecturers and demonstrators, by 31.6 per cent to 1,548 . In science, however, the staff increased. by 33.6 per cent compared with a $44 \cdot 1$ per cent increase in students, and in applied science by 45 per cent compared with a 37.9 per cent increase in students.

Recurrent expenditure increased from about $£ 42$ million in $1956-57$ to $f 74$ million in 1961-62-by far the largest increase being more than $£ 13$ million in the salaries and superannuation of teaching staff which accounts for about 43 per cent of total university expenditure. Changes in technicians' wages have also seriously affected the universities' budgets. The Committee expresses concern lest extension of supplementation to cover individual categories of expenditure beyond academic salaries and local rates should encroach on the quinquennial system to an extent endangering the universities' freedom of choice in allocating recurrent funds. University income rose from $£ 41.7$ million to $£ 74 \cdot 1$ million in the same period, the percentage derived from Treasury recurrent grants increasing from $67 \cdot 8$ to $69 \cdot 5$. Payments for research rose from 6.5 per cont to 11.1 per cent at $£ 8.2$ million; the percentages derived from fees, endowments, grants from local authorities and donations and subscriptions all decreased slightly during the quinquennium, although the actual amounts rose. The recurrent grants announced in March 1962 for the 1962-67 quinquennium totalling $£ 329$ million have been increased by subsequent supplementary grants to $£ 385$ million, distributed approximately over the successive years as follows: $1962-63$, $£ 61$ million; 1963-64, £72 million; 1964-65, £78 million; $1965-66$, $£ 84$ million; 1966-67, £91 million. Non-recurrent grants also increased during the quinquennium, totalling almost $£ 125$ million (excluding $£ 2.2$ million for provision of computers); 73 per cent of the total represented buildings and fees, 22 per cont furniture and equipment and 5 per cent sites and properties. Of expenditure on approved 
building projects 55 per cent was for science and applied science buildings, 5 per cent for libraries, and 20 per cent for student residences.

In the chapter on university expansion the Committee details the considerations which led to the conscious planning of expansion from 80,600 places in $1953-54$ to 70,000 in $1973-74$ and then the considerations which influence its views on the size and location of universities. It believes that many of the university institutions in Britain are still too small to be academically or economically viable, and that the weight of argument generally is in favour of larger institutions. Growth in the number of subjects and in their coverage as well as the increasing responsibilities of the universities in the search for new knowledge led to greater specialization and greater size, whilo tho increasing costliness of research through the need for expensive equipment and extensive library provision necessitates maximum utilization of resources and some degree of concentration in thoir availability. The universities are in fact already becoming bigger, and whilo the major part of the increase between 1953-54 and 196667 will be found in the English civic universities, the further planned expansion of 20,000 places by 1973-74 will take place almost entirely in the civic universitiesthe seven now universities providing about 14,000. By the end of the present quinquennium in 1966-67, the faculties of pure and applied science will contain $46 \cdot 6$ per cent of the students, arts and social studies $39 \cdot 3$ per cent and medicine and dentistry $11 \cdot 6$ per cent. The outstanding increase in the proportion of students studying pure and applied science is due essentially to a relative stability in tho numbers studying medicine, dentistry, agriculture and veterinary science.

The Committee believes that the time is right for further consideration of the postgraduate degree structure. In commenting that the coming expansion will necessitato the broadening of undergraduate education, it refers to the need for more fundamental thinking on the purposes of university education, the qualities of mind it should develop, and whether these are fostered sufficiently by the courses offered and the kind of life the student lives. On the basis of costs in 1961-62, it estimates the capital cost of expansion as being about $£ 1,200$ for an additional place in arts, $£ 2,400$ in science and $£ 3,500$ in applied science. The total capital cost per student place of a conventional hall of residence at an existing university is put at about $£ 1,800-£ 1,850$; alternatives are being explored such as the provision of student flats which could bring the figure to below $£ 1,500$. Conversion to student use of suitably large houses in the vicinity of a university offers a possibility of meeting a substantial proportion of the need at about $£ 600$ a head. To provido residontial accommodation for about two-thirds of the increase to 70,000 students by the early 1970's would increase the per capita cost by about $£ 1,000$ to a total figure of about $£ 3,000$ por student place in both existing and new universities.

The chapter on the new universities gives a concise account of the various proposals and first steps for now universities, the pattern of their development, including the factors which determined their location, the academic planning boards and thoir terms of reforence and the new lines of development in univorsity government, coverage, academic advisory committees and experiments in breadth of curricula, student organization and residence and in teaching methods. A chapter on the growth and control of capital expenditure covers the various points which have been at issue with the Public Accounts Committee or the Estimates Committee and which were investigated by the Gater Committee and Sir Arthur Rucker. The University Grants Committee emphasizes that for the effective and oconomic execution of building programmes close and eontinuous consultation between the universities' officers, including, subject to the university's agreement, their professional advisers and the Committeo's officers, is essontial. Except with minor works, no commitment should be enterod into for which grant-in-aid is to be sought without prior approvel by the University Grants Committee, and oneo its approval has beon given to a particular proposal or a building schedule, no change should be made which might increaso the amount for which grant-in-aid is sought without the Committeo's agreement. The Committee is not prepared to recommend for grant expenditure which has not been agreed by it in advance. There is also some discussion of the division of responsibility between the Committee and the Research Councils for the provision of research equipment, but generally the assessor system has worked well. In a chapter on academic salaries and staffing, the Committee comments that over the years the proportion of academic recruits with first-class degrees has declined, as has the overall proportion of firsts among graduates. It points out that changes in the post-war years suggest that the first need is improvement in salaries and career prospects if standards of teaching and research are not to be allowed to continue to decline. Even greater improvement will be needed if further expansion is to be achieved without a yet groater fall in standards.

\section{TECHNOLOGY AND THE SIXTH FORM IN SCHOOLS}

A CONFERENCE, organized by the British Petroleum Co., Ltd., was held in London during February 29March 1 under the chairmanship of Mr. A. D. C. Poterson, at which school, university and technical college teachers considered the implications of the Oxford report on Technology and the Sixih Form Boy (soo Nature, 199, 958 (1963); 200, 219 (1963)).

Discussion hinged on four main issues-the 'image' of the technologist, the transition between pure and applied science, the transition from school to college and university and the possibility of teachers adding to their professional skills by gaining appropriate experience within industry.

In considering the 'image' of the technologist in Britain, the conference emphasized the need to correct the nebulous impression of the technologist, held by the public (and especially by parents), by boys and girls and by teachers. Possible lines of action were the production of good technical films, the organization of public loctures by enthusiasts (to be given before a student entered the sixth form), more works visits with an emphasis on the jobs that are done, a broadening of the activities of the Institutes of Education to include visits, technological lectures and vacation attachments, the introduction into schools of minor projects, further development in the visiting of colleges of advanced technology and universities and the employment of technologists as staff and visiting staff.

To help the transition between pure and applied science, various suggestions were made. The principles of pure science could bo illustrated from applied science and, to help, mobile laboratories should bo made available together with films that were more appropriate than the rather elementary ones at presont available. Some adjustment of the science syllabus would also contribute and, again, the 'image' of technology needed correction if pupils and teachers were to develop a greater awaroness of the relationship between the two areas.

As for the actual teaching of technological material, the conference felt that this should spring from daily teaching - ongineering drawing, for example, should arise from studios in geometry at the Ordinary Level of the General 